\title{
Relação entre variação de tom médio da fala e comportamento do falante ${ }^{7}$
}

\author{
Thiago Martins
}

O trabalho tem inicialmente como objetivo analisar a variação de tom médio da fala em relação com o comprometimento do falante com a impressão de verdade que ele quer passar. Isso envolve a prosódia de um indivíduo e consequentemente as emoções com as quais ele está envolvido no ato da fala.

A comunicação é algo vital e natural do ser humano. O indivíduo é um ser que carrega crenças e ao observar falantes em seus atos de comunicação, há momentos em que as verdades individuais de um se confrontam com as de outro. É assim nos debates, seja de cunho científico, familiar ou até político, onde o extremo desse confronto pode resultar em guerras atrozes, as quais a humanidade já vivenciou.

A fala é o correlato mais direto e o indicador mais poderoso de processos emocionais (SCHERER, 1989). A ciência da linguagem evoluiu a ponto de medir e descrever, com uma exatidão que a leva ser uma ciência, as variações do sistema linguístico e meios através do qual ele se manifesta.

Scherer (2001) afirma que a voz é controlada por processos fisiológicos, onde há uma ligação psíquica. Sendo assim, variações psicofisiológicas podem ser medidas através da fala.

\footnotetext{
${ }^{7}$ SIMPÓSIO INTERNACIONAL DE INICIAÇÃO CIENTÍFICA/USP - SIICUSP, 18. São Paulo, 2010.
} 
Um exemplo disso é quando o indivíduo se encontra bravo em seu estado emocional, isso faz com que seus músculos da laringe fiquem mais tensos, mais contraídos e consequentemente haverá um aumento do FO (frequência fundamental) na voz. Esses efeitos internos do organismo que repercutem na voz são chamados de push-effects, se contrapondo com os pull-effects. Estes seriam, segundo Scherer, convencionalizados, são variações na fala que são de ordem social, seja simplesmente por necessidade de comunicação, ou então até por limitações do ambiente. Também nesse âmbito, Fónagy (2003) dá diferentes funções para as variações prosódicas. Em suas categorias entram tanto as convencionais (função sintática ou de ênfase) quanto as que seriam naturais (função expressiva, relacionada às emoções).

Com base nessa distinção (push and pull-effects), pode-se utilizar os parâmetros vocais para inferir variações emocionais.

A questão da arbitrariedade repercute neste trabalho. Vários estudos feitos por Scherer (SCHERER, 2001) ambicionam descobrir as relações das manifestações da emoção na fala entre culturas, buscando saber se a expressão da emoção seria algo universal ou relativamente cultural. Tal indagação se volta para a questão da própria emoção como algo biológico ou adquirido culturalmente, levando em consideração suas funções. No reconhecimento da expressão emocional através da fala, seria eu capaz de ter a mesma percepção e fazer as mesmas inferências em indivíduos pertencentes a outras culturas e falantes de outras línguas?

Para saber como se dá tal manifestação da emoção através da fala dentro da cultura brasileira e por falantes de português brasileiro, o parâmetro acústico em foco foi o tom médio do falante, ou seja, a variação da sua frequência fundamental. Então o trabalho em apresentação foi desenvolvido da seguinte maneira: 
O corpus foi retirado de vídeos do Youtube, em que o conteúdo apresentado é um debate presidencial que ocorreu ao vivo e online. Foi feita a segmentação de alguns trechos relevantes do discurso de um dos participantes com a intenção de contrapor momentos em que o falante se encontrava aparentemente tranquilo com momentos em que ele apresentava alteração emocional de acordo com sua expressão. Foram separados 4 trechos de cada tipo: 4 em que o estado aparentava estar tranquilo e 4 em que ele estava alterado. Tanto a segmentação dos trechos como a análise dos valores de intensidade e de frequência fundamental da fala foram feitos através do programa SFS (Speech Filing System). Com os dados obtidos dos segmentos, os valores foram submetidos ao ExProsódia, um programa desenvolvido pelo professor Waldemar Ferreira Netto que tem como objetivo a análise automática da prosódia. Através desse programa foi calculado o tom médio em Hertz da fala de cada trecho:

\begin{tabular}{|l|c|c|}
\hline & Alterado & Não alterado \\
\hline & 166 & 111 \\
\hline & 141 & 119 \\
\hline & 151 & 104 \\
\hline & 174 & 135 \\
\hline Média & 158 & 117,25 \\
\hline
\end{tabular}

Já pela observação dos dados pode-se notar que os valores da coluna da esquerda são maiores do que as da direita. Para a confirmação de resultados, nos valores de tom médio acima foi aplicado o teste $F$, por meio do qual foram obtidas as médias dos valores das duas colunas e feita uma análise estatística desses dados. Com isso teve-se um $\mathrm{P}=0,006(<0,01)$ e um Fo $(16,73)>F c(5,99)$. Através de tal teste os dados apresentados na análise se mostram significativos. 
Com isso, neste pequeno trabalho, os dados apresentados demonstram que na língua portuguesa falada no Brasil também se vê um aumento da variação da frequência fundamental, e portanto um aumento de tom médio da voz, relacionado com a emoção do falante. Isso nos aponta para a hipótese inicial de que o comprometimento do falante com a impressão de verdade de seu discurso tem relação com o tom médio de sua fala. Pode-se concluir, portanto, que tal comportamento se manifesta precisamente através da fala e junto com outros trabalhos a respeito do mesmo tema pode-se buscar uma generalização a respeito do caráter natural ou social de tais comportamentos e manifestações. Para tanto, não se pode deixar de pensar em tais objetos de estudos sem levar em consideração o ser humano e os contextos variados em que se insere, até mesmo sua capacidade de manipulação de seus recursos naturais. 